\title{
Induction of new chitinase isoforms in tomato roots during interactions with Glomus mosseae and/or Phytophthora nicotianae var parasitica
}

\author{
MJ Pozo 1*, E Dumas-Gaudot 2, S Slezack 2, C Cordier 2, A Asselin 3, \\ $S$ Gianinazzi 2, V Gianinazzi-Pearson 2, C Azcón-Aguilar 1, JM Barea ${ }^{1}$ \\ 1 Estación Experimental del Zaidin, CSIC, 18008 Granada, Spain; \\ ${ }^{2}$ Laboratoire de Phytoparasitologie Inra-CNRS, CMSE, Inra, BV 1540, 21034 Dijon cedex, France; \\ ${ }^{3}$ Département de Phytologie, FSAA, Université Laval, Quebec, G1K7P4, PQ Canada
}

(Received 30 July 1996; accepted 23 September 1996)

\begin{abstract}
Summary - Chitinase activities were investigated by native and denaturing SDS-PAGE in tomato roots during symbiosis with the arbuscular mycorrhizal (AM) fungus Glomus mosseae, in a pathogenic interaction with Phytophthora nicotianae var parasitica and in pathogen-infected roots pre-inoculated with $G$ mosseae for 2 weeks. Several native acidic chitinase isoforms were found in control roots. One additional isoform was detected in $G$ mosseaecolonized roots, while a different one was found in pathogen-infected roots, as well as stronger expression of constitutive isoforms. All the chitinase isoforms were found in tomato roots pre-inoculated with $G$ mosseae and post-infected with the pathogen. Four basic isoforms were present in all extracts, but they only showed enhanced activities in pathogeninfected roots. Chitinases from AM roots renatured more quickly and easily than those from non-mycorrhizal roots, after denaturing under non-reducing conditions, even when mycorrhizal plants were post-infected with the pathogen.
\end{abstract}

tomato / Glomus mosseae / Phytophthora nicotianae var parasitica / chitinase bioprotection

Résumé - Induction de nouvelles isoformes de chitinase dans les interactions des racines de tomate avec Glomus mosseae et/ou Phytophthora nicotianae var parasitica. Les activités chitinases de racines de tomate en symbiose avec le champignon mycorhizogène Glomus mosseae, dans une interaction pathogène avec Phytophthora nicotianae var parasitica et dans des racines colonisées par $G$ mosseae depuis deux semaines et post-infectées par le pathogène ont été étudiées en gels d'électrophorèse natifs (Page) et dénaturants (SDS-Page). En conditions natives, les racines témoins ont révélé plusieurs isoformes acides de chitinase. Une isoforme additionnelle a été détectée dans les racines colonisées par $G$ mosseae, tandis qu'une isoforme additionnelle différente et une plus forte expression des isoformes constitutives ont été observées dans les racines infectées par le pathogène. Quand les racines étaient mycorhizées puis infectées par le pathogène, l'ensemble des isoformes induites par les deux champignons a été détecté. Sur les quatre isoformes basiques présentes dans tous les extraits, seules les activités des racines infectées par le pathogène étaient stimulées. Après dénaturation en conditions non réductrices, les isoformes de chitinase des racines mycorhizées se sont renaturées plus rapidement et plus facilement que celles des racines non mycorhizées et cela même lorsque les plantes mycorhizées ont été ultérieurement infectées par le pathogène.

tomate / Glomus mosseae / Phytophthora nicotianae var parasitica / chitinase bioprotection

\footnotetext{
${ }^{*}$ Correspondence and reprints
} 


\section{INTRODUCTION}

Arbuscular mycorrhizal (AM) associations have been shown to be effective in the biological control of soil-borne plant pathogens (Linderman, 1994). Investigations of mechanisms related to increased resistance to pathogens in mycorrhizal plants indicate that these are probably complex. Indeed, enhanced mineral nutrition, stress alleviation, microbial changes in the rhizosphere, competition with the pathogen for nutrients and infection sites, modifications in root system morphology, anatomical changes such as increased lignification of root endodermal cells, and biochemical alterations in plant tissues are the most frequently evoked mechanisms (Hooker et al, 1994; Linderman, 1994). Qualitative and quantitative alterations in protein expression have been reported in various AM associations (Dumas et al, 1989; Pacovsky, 1989; Wyss et al, 1990; Arines et al, 1993, 1994a; Schellenbaum et al, 1993; Dumas-Gaudot et al, 1994b), but only weak, very local or transient induction of plant defence mechanisms seems to occur in AM symbiosis (Gianinazzi-Pearson et al, 1994).

When plants respond to attack by pathogenic microorganisms, a range of reactions are triggered, including the expression of a large number of genes encoding proteins related to defence. Among these, chitinases can be strongly induced in response to pathogen infections. These enzymes often act synergically with $\beta-1,3-$ glucanases, playing an important role in defence responses against fungal infection (Boller, 1993). Chitinases are able to partially degrade fungal cell walls by hydrolyzing chitin, a linear homopolymer of $\beta-1,4$ linked $N$-acetylglucosamine residues, which is one of the major cell wall components of most fungi (Wessels and Siestma, 1981). Chitinases exist as a family of proteins differing in their biochemical characteristics, primary structures and subcellular localization. They can be differentially regulated, probably playing different roles (Collinge et al, 1993; Graham and Sticklen, 1994). Furthermore, although their precise function in symbiotic interactions is still unclear, stimulation of plant chitinase activities has been reported in several root symbioses such as soya bean nodules (Staehelin et al, 1992), ectomycorrhiza (Albrecht et al, 1993) and arbuscular mycorrhiza (Spanu et al, 1989; Dumas-Gaudot et al, 1992 a, b, 1994a; Volpin et al, 1994).

In an attempt to evaluate changes in some hydrolytic activities associated with mycorrhiza- induced resistance of tomato roots to Phytophthora nicotianae var parasitica, several experiments have been carried out to investigate chitinase isoforms expressed during symbiosis with Glomus mosseae, infection by $P n$ var parasitica and during induced resistance to the pathogen in mycorrhizal roots.

\section{MATERIALS AND METHODS}

\section{Chemicals}

All chemicals for electrophoresis, analytical grade mixed bed resin AG 501-X8 (20-50 mesh), prestained protein molecular mass markers, and Coomassie Brilliant Blue R 250 were from Bio-Rad (Ivry-sur-Seine, France). All other compounds were from Sigma Chemical Co (Saint-Quentin-Fallavier, France). Glycol chitin was synthesized as previously described (Trudel and Asselin, 1989).

\section{Plant and fungal material}

A soil (Epoisses)-based mycorrhizal inoculum of Glomus mosseae (Nicol and Gerd) Gerdemann and Trappe (BEG12) containing fungal propagules and chopped mycorrhizal Allium porrum $L$ roots was used. The root pathogen Phytophthora nicotianae var parasitica isolate 201 (kindly provided by $\mathrm{P}$ Bonnet, INRA, Antibes, France) was grown in $9 \mathrm{~cm}$ petri dishes on a malt-agar $\left(2 \% / 1 \%\right.$, w/v) medium, at $25^{\circ} \mathrm{C}$ in darkness for 3 weeks. Inoculum was prepared by washing the growing mycelia with sterile water ( $15 \mathrm{~mL} / \mathrm{dish})$ and the mycelial suspension obtained was used to inoculate tomato plants by directly watering the root system (7 mL/plant).

Tomato seeds (Lycopersicon esculentum cV Earlymech) were surface sterilized with $3.5 \%(\mathrm{w} / \mathrm{v})$ calcium hypochlorite and germinated in sterile vermiculite at $22{ }^{\circ} \mathrm{C}$ under light for 10 days. Control plants were transplanted into a mixture of $\gamma$-irradiated soil from Epoisses (pH 7.4, 26 ppm available Olsen P) and calcined montmorillonite clay (Oil Dry US-special type III$\mathrm{R}$, IMC Imcore) (1:1, v/v) (one plant/400 $\mathrm{mL}$ mixture). For mycorrhizal experiments, seedlings were transplanted into a mixture of the $G$ mosseae-soil inoculum and calcined clay $(1: 1, \mathrm{v} / \mathrm{v})$. Half of the plants from both control and mycorrhizal treatments were inoculated with $P n \vee$ parasitica 2 weeks after transplanting as described earlier. Such a delayed inoculation time with the pathogen was chosen because bioprotection by mycorrhizal fungi occurs mainly when they have precolonized plants before the pathogen attack (Linderman, 1994; Cordier et al, 1996). Experiments were repeated three times.

All plants were grown in a controlled environment room $\left(23{ }^{\circ} \mathrm{C} / 18{ }^{\circ} \mathrm{C}\right.$ day/night, $60 \%$ relative humidity, $16 \mathrm{~h}$ photoperiod at $300 \mu \mathrm{mol} \mathrm{m}-2 \mathrm{~s}^{-1}$ ). They were 
watered daily with deionized water and weekly with 50 $\mathrm{mL} /$ pot of Long Ashton nutrient solution (Hewitt, 1966) at normal phosphorus concentration for control plants and at one-tenth phosphorus strength for mycorrhizainoculated ones in order to get similar physiological and nutritional status in mycorrhizal and non-mycorrhizal plants. Tomato roots were harvested 4 weeks after transplanting, carefully washed in running tap water, rinsed in deionized water and weighed. They were then immediately frozen in liquid nitrogen, and stored at $-65^{\circ} \mathrm{C}$ until protein extraction.

\section{Quantification of arbuscular mycorrhizal colonization and pathogenic infection}

At harvest, samples from root systems were stained as described by Phillips and Hayman (1970). Mycorrhizal colonization was expressed by the percent of colonized cortex in the root system (M\%), according to Trouvelot et al (1986). The spread of $P n \vee$ parasitica was visually estimated as the percentage of necrotic lesions of the root system as described by Cordier et al (1996).

\section{Protein extraction, electrophoresis and enzymatic assay}

Frozen roots were ground at $4{ }^{\circ} \mathrm{C}$ in an ice-chilled mortar with liquid nitrogen and the resulting powder suspended in $100 \mathrm{mM}$ Macllvaine (citric acid/ $/ \mathrm{Na}_{2} \mathrm{HPO}_{4}$ ) extracting buffer, $\mathrm{pH} 6.8(1: 1, w / v)$. Crude homogenates were centrifuged at $15000 \times g$ for 30 $\min$ at $4{ }^{\circ} \mathrm{C}$ and the supernatant fractions were kept frozen at $-20^{\circ} \mathrm{C}$. $P n \vee$ parasitica mycelium extracted in the same buffer was included to test chitinase activities of the pathogen, either as crude extracts or after the supernatant had been lyophilized and the resulting powder dissolved in a minimal amount of Mcllvaine buffer. All extracts were analyzed by $15 \%(\mathrm{w} / \mathrm{v})$ polyacrylamide gel electrophoresis (PAGE) under native conditions at $\mathrm{pH} 8.9$ according to Davis (1964) and at $\mathrm{pH} 4.3$ as described by Reisfeld et al (1962). Denaturing gels with sodium dodecyl sulphate (SDSPAGE) were used as described by Trudel and Asselin (1989). For Davis and SDS-PAGE, $0.01 \%(\mathrm{v} / \mathrm{v})$ of glycol chitin (chitinase substrate) was embedded in the gels, while when using the Reisfeld system, glycol chitin was added in a $7.5 \%(\mathrm{w} / \mathrm{v})$ polyacrylamide overlay gel. Transfer of proteins to the overlay gel was done by blotting for $4 \mathrm{~h}$ according to Audy et al (1988).

SDS-PAGE separations were carried out under both reducing and non-reducing conditions, and different methods were used to restore enzymatic activities. Samples were denatured under reducing conditions by boiling $5 \mathrm{~min}$ in the denaturing buffer (Trudel and Asselin, 1989) containing 5\% (v/v) 2-mercaptoethanol. Renaturation of chitinase activities after SDS-PAGE was carried out by a $20 \mathrm{~min}$ wash at $37^{\circ} \mathrm{C}$ in $200 \mathrm{~mL}$ of $100 \mathrm{mM}$ Tris- $\mathrm{HCl}$ buffer ( $\mathrm{pH} 8.0)$ containing $1 \%(\mathrm{v} / \mathrm{v})$ purified triton $X-100$ and $1 \mathrm{mM}$ thioglycolate or $1 \mathrm{mM}$ cysteine, followed by a $45 \mathrm{~min}$ incubation at $37^{\circ} \mathrm{C}$ in buffered triton X-100 ( $\mathrm{J}$ Grenier, personal communication). For non-reducing conditions, samples were similarly boiled, omitting 2-mercaptoethanol, according to Trudel and Asselin (1989). After electrophoresis, renaturation was done by a 20 min wash in $200 \mathrm{~mL}$ of 50 $\mathrm{mM}$ sodium acetate $(\mathrm{pH} 5.0)$ with $1 \%(\mathrm{v} / \mathrm{v})$ purified triton $X-100$, followed by incubation at $37^{\circ} \mathrm{C}$ in buffered triton $X-100$ solution. Several incubation times ranging from 1 to $18 \mathrm{~h}$ were tested.

All electrophoreses were repeated at least three times. Chitinase activities on gels were revealed by fluorescent staining using calcofluor white M2R $(0.01 \%$, $w / v)$ in $500 \mathrm{mM}$ Tris- $\mathrm{HCl}(\mathrm{pH} 8.9)$ and visualized after destaining under ultraviolet $(365 \mathrm{~nm})$ light. Gels were photographed using one orange filter and Polaroid 665 film. Gels were also stained with Coomassie blue R250 followed by aqueous silver nitrate as specified by Trudel and Asselin (1989).

\section{RESULTS}

The common aspect of uninoculated tomato roots is shown in figure $1 \mathrm{~A}$. The root system appeared more developed in $G$ mosseae-inoculated roots (fig $1 \mathrm{C}$ ). Necrotic lesions were obvious on roots infected with $P n \vee$ parasitica (arrows on fig 1B). The percentage of root length with necrosis reached $19 \%$. When tomato plants were pre-inoculated for 2 weeks with $G$ mosseae and post-infected with Phytophthora for 2 weeks (fig 1D), the root system was clearly less affected by the pathogenic attack, and the frequency of necrotic lesions was significantly reduced by more than $50 \%$ as compared to non-mycorrhizal Phytophthora-infected ones. These results are in agreement with those from Cordier et al (1996).

In the Davis electrophoretic system for separating acidic or neutral proteins, crude extracts

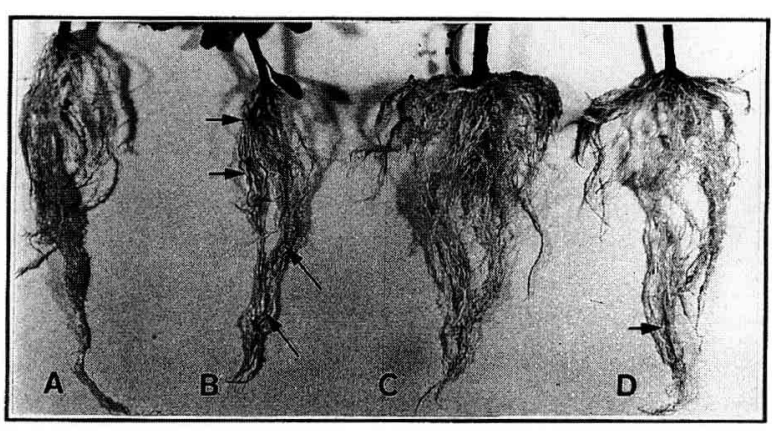

Fig 1. Tomato root systems from uninoculated $(\mathbf{A})$, and inocu lated plants with Phytophthora nicotianae var parasitica for 2 weeks (B) or with Glomus mosseae for 4 weeks (C), or precolonized with $G$ mosseae for 2 weeks and post-infected for 2 weeks with $P n$ v parasitica (D). All plants were harvested 4 weeks after transplanting. Arrows in $\mathbf{B}$ and $\mathbf{D}$ show necrotic lesions 


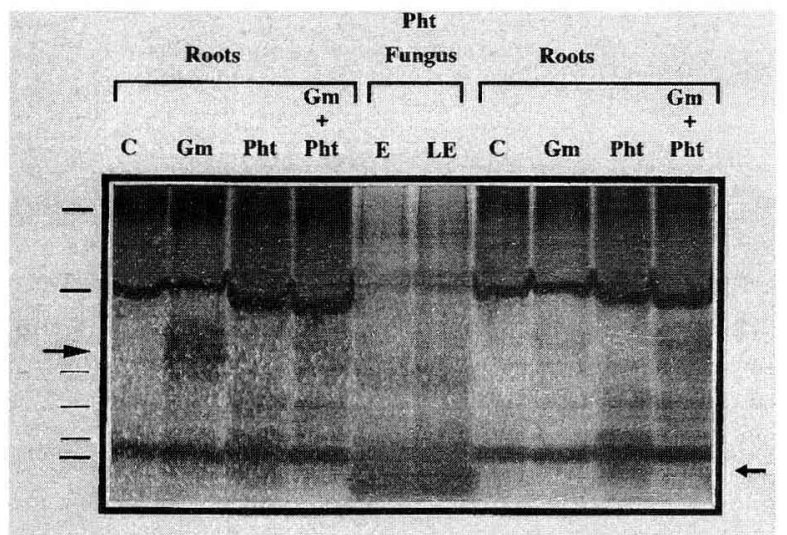

Fig 2. Acidic chitinase activities after separation of proteins by Davis system in $15 \%(\mathrm{w} / \mathrm{v})$ polyacrylamide gels containing $0.01 \%(w / v)$ glycol chitin as substrate. Root extracts in Mcllvaine buffer $(100 \mathrm{mM}, \mathrm{pH} 6.8)$ from uninoculated control tomato plants (C), Glomus mosseae-inoculated (Gm), Phytophthora nicotianae var parasitica-infected (Pht), inoculated with both fungi (Gm + Pht) and crude $(E)$ or lyophilized (LE) extracts from the pathogenic fungus $P \cap \vee$ parasitica ( $P$ ht Fungus) were tested. All root samples contained $20 \mu \mathrm{g}$ of fresh weight material. On the left side are results from one experiment in which $G$ mosseae-inoculated roots displayed a colonization level reaching $30 \%$; on the right side are results corresponding to samples from roots with a lower colonization level $(19 \%)$ ( $\mathrm{M} \%$ estimated according to the method from Trouvelot et al, 1986). Gels were stained with calcofluor white M2R, visualized and photographed under ultraviolet light according to Trudel and Asselin (1989). Constitutive chitinase isoforms are indicated by bars, additional isoforms by arrows.

from control tomato roots showed three main bands and three other faint bands, corresponding to constitutively expressed chitinase isoforms (fig 2 , lanes $C$ ). The two lower main bands are certainly true acidic/neutral isoforms while the upper one could be a basic isoform also separated in the Davis system. The other faint additional bands were more or less expressed in different experiments and their intensity could be related to stress situations. One additional chitinase isoform was observed in extracts from $G$ mosseaecolonized tomato roots (fig 2, left panel, lane $\mathrm{Gm}$, arrow on the left) where the level of AM colonization of roots reached $30 \%$. The additional chitinase isoform was only very weak in extracts of roots with lower colonization ( $M=19 \%$ ) (fig 2, right panel, lane $\mathrm{Gm}$ ). In $P n$ v parasitica-infected roots the second main and the three faint constitutive tomato isoforms were strongly stimulated and one additional chitinase isoform, which could not be observed in control roots, was also detected (fig 2, lane Pht, arrow on the right). No lytic bands with similar mobilities occurred in crude (E) or lyophilized (LE) extracts from living mycelium of $P n \vee$ parasitica. All the bands corresponding to chitinase activities induced by both fungi were detected in root extracts from mycorrhizal tomato post-infected with $P n \vee$ parasitica, although the mycorrhiza-related isoform activity appeared to decrease (fig 2, lanes Gm + Pht).

Basic chitinase isoforms were analyzed using the Reisfeld gel electrophoretic system. Four main constitutive basic isoforms were observed and no qualitative differences were detected between the different treatments (fig 3 ). Stronger signals for chitinase activities were visualized in extracts from $P n \vee$ parasitica-infected tomato roots (fig 3 , lane Pht). Similar increases were not found in extracts from AM roots post-infected with $P \cap$ v parasitica (fig 3 , lane $\mathrm{Gm}+\mathrm{Pht}$ ). A crude extract from the pathogenic fungus (fig 3 , Fungus lane) did not show clear basic chitinase activity corresponding to those observed in any of the root extracts.

When chitinase activities were analyzed by SDS-PAGE under non-reducing conditions, only root chitinase isoforms from mycorrhizal roots were renatured within short incubation times (fig 4, panel A). Three well-defined lytic bands with apparent molecular masses (MW) ranging from 28 to $35 \mathrm{kDa}$ appeared after only $1 \mathrm{~h}$ incubation, even when plants had been post-infected with the pathogen (fig 4, panel A, lanes $\mathrm{Gm}$ and $\mathrm{Gm}+$ Pht). Some of these bands were faintly observed in $P \cap \vee$ parasitica-infected roots but only after a longer renaturation time ( $8 \mathrm{~h}$ ) (fig 4 , panel $B$, lane Pht). Additional bands with chitinase activities

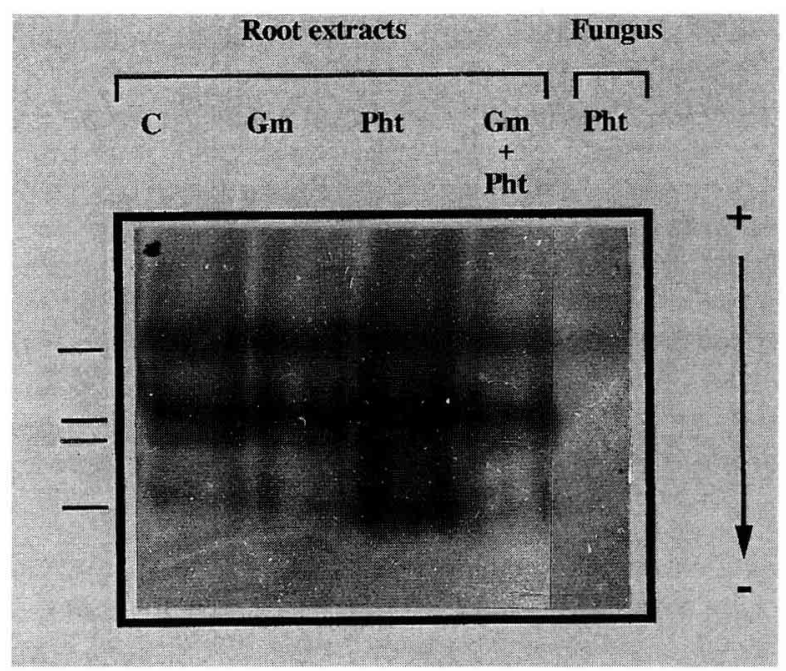

Fig 3. Basic chitinase activities after separation in $15 \%(w / v)$ polyacrylamide gels using the Reisfeld system and blotting of proteins through a $7.5 \%$ overlay gel containing $0.01 \%(\mathrm{w} / \mathrm{v})$ glycol chitin as substrate. Root extracts in Mcllvaine buffer from uninoculated control tomato plants (C), Glomus mosseae-inoculated (Gm), Phytophthora nicotianae var parasitica-infected (Pht), inoculated with both fungi (Gm + Pht) and a crude extract from the pathogenic fungus (Fungus Pht) were analyzed. All root samples contained $20 \mu \mathrm{g}$ of fresh weight material. Constitutive chitinase isoforms are indicated by bars on the left. Chitinase activities were detected as in figure 2 
displaying lower MW were detected in all root extracts with the longer renaturation time, but considerably stronger in those from Phytophthora-infected plants. No similar chitinase activity was found in crude extracts of the fungal pathogen (fig 4 , panels $A$ and $B$, lanes Fungus Pht). After SDS-PAGE under non-reducing conditions, the chitinase activities from mycorrhizal roots were slightly reduced by the pathogen attack (fig 4, panels $A$ and $B$, lane $G m$ + Pht). When denaturation was carried out under reducing conditions (fig 4 , panels $C$ and $D$ ), three chitinase activities corresponding to isoforms with molecular masses ranging from 28 to $35 \mathrm{kDa}$ were observed in all root samples, but not in extracts of the fungal pathogen (fig 4, panels $C$ and $D$, lanes Fungus Pht). These results confirm recent data showing better renaturation of some plant chitinases under reducing conditions when either thioglycolate or cysteine are added to the renaturing buffer (Asselin et al, unpublished results). Moreover, this process allows determinations of protein molecular masses. There was no difference in isozyme banding between

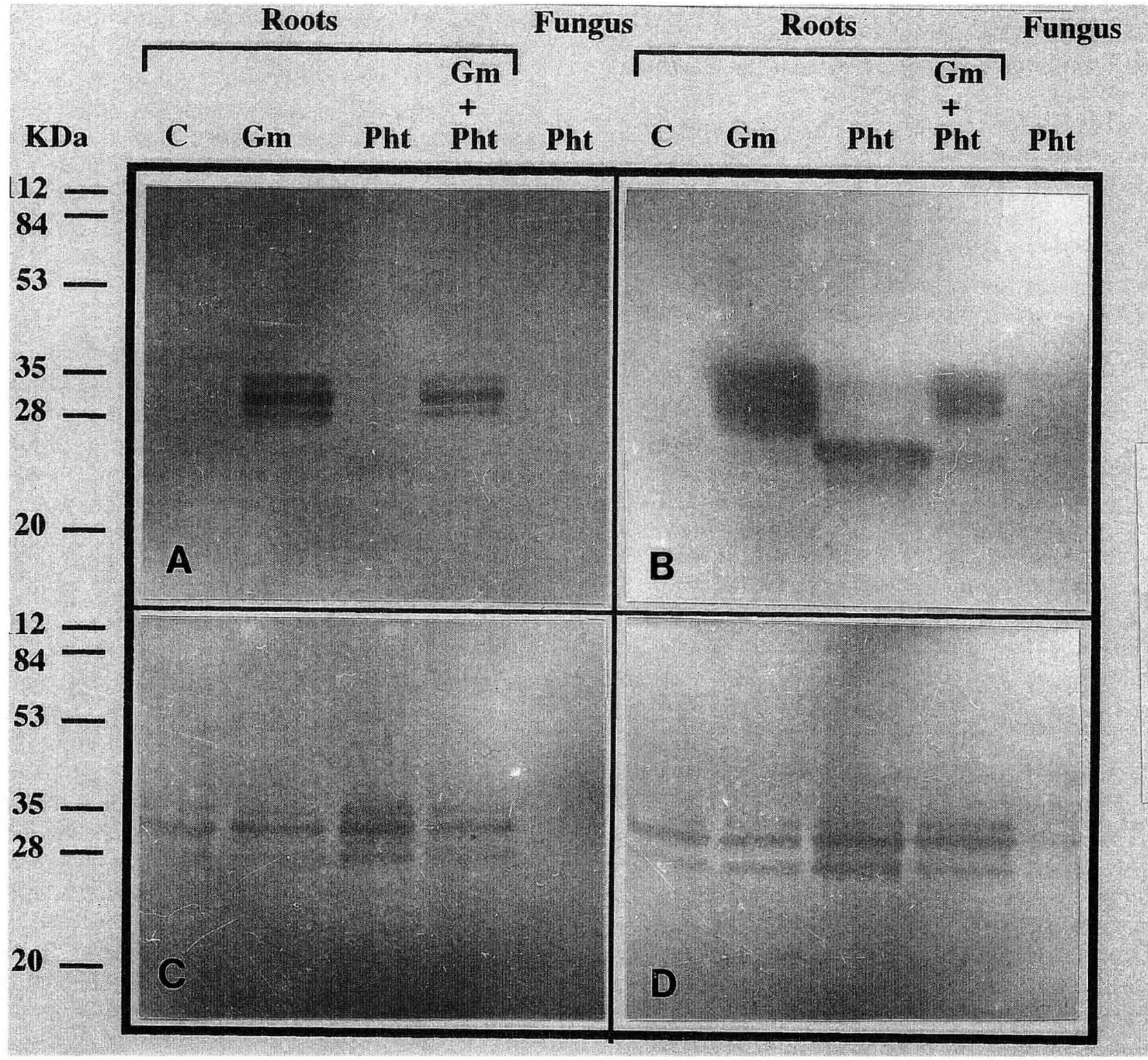

Fig 4. Chitinase activities after denaturing $15 \%(\mathrm{w} / \mathrm{v})$ polyacrylamide gel electrophoresis (SDS-PAGE). Root extracts from uninoculated control tomato plants (C), Glomus mosseae-inoculated (Gm), Phytophthora nicotianae var parasitica-infected (Pht), inoculated with both fungi $(\mathrm{Gm}+\mathrm{Pht})$ and a crude extract $(\mathrm{E})$ from the pathogenic fungus (Fungus Pht) were tested. All root samples contained $15 \mathrm{mg}$ of fresh weight material. In panels $\mathbf{A}$ and $\mathbf{B}$, before being submitted to SDS-PAGE, the samples were boiled in denaturing buffer without 2-mercaptoethanol; renaturation was done following Trudel and Asselin (1989) during 1 and $8 \mathrm{~h}$, respectively. In panels C and D samples were denatured in the presence of 2-mercaptoethanol, submitted to SDS-PAGE and renatured in $100 \mathrm{mM} \mathrm{TRIS-HCl-triton} \mathrm{X-}$ 100 buffer plus $1 \mathrm{mM}$ thioglycolate (panel C) or $1 \mathrm{mM}$ cysteine (panel D) for $45 \mathrm{~min} ; 12.5 \mu \mathrm{g}$ of total prestained molecular markers (kDa) (low molecular weight kit from Bio-Rad, France) were loaded in each gel and are indicated by bars on the left. 
uninoculated and inoculated tomato roots using thioglycolate or cysteine, although stronger signals were detected in extracts from $P \cap \vee$ parasitica-infected roots in both cases. The determined molecular masses were similar to those estimated by the non-reducing procedure, ranging from 28 to $35 \mathrm{kDa}$, which is usual for plant chitinases (Collinge et al, 1993; Graham and Sticklen, 1994).

\section{DISCUSSION}

As has been described before for other AM fungiplant-pathogen interactions, previous colonization of the root system by $G$ mosseae exerted a protective effect on tomato plants against $P n v$ parasitica. This protection was reflected in a reduction of the necrotic lesions in the root system, as well as a lower decrease in the root size in comparison to non-mycorrhizal plants infected with $P n$ v parasitica.

The induction of plant chitinases and $\beta-1,3$-glucanases after the inoculation of tomato leaves with pathogenic fungi and viruses, or treatments with chemicals has been widely reported (Pegg and Young, 1982; Granell et al, 1987; Joosten and de Witt, 1989; Garcia-Breijo et al, 1990; van Kan et al, 1992; Wubben et al, 1992; Joosten et al, 1995). From these reports, in pathogen or chemically treated tomato leaves, four chitinases were identified: two acidic extracellular chitinases with MW of 26 and $27 \mathrm{kDa}$ and two basic intracellular ones with $\mathrm{MW}$ of 30 and $32 \mathrm{kDa}$. Recently, the existence of an additional $20 \mathrm{kDa}$ protein with chitinase activity has been reported (Joosten et al, 1995). Very few reports, however, deal with tomato root/fungal interactions (Benhamou et al, 1989, 1990), and these are limited to ultrastructural enzyme localization during Fusarium oxysporum infections.

Our study evidences for the first time the presence of several molecular forms of chitinases in tomato roots by means of PAGE associated with a specific test for chitinase activity, as described before for chitinase isoform detection on tobacco leaves (Trudel et al, 1989; Pan et al, 1991). Since proteins with pl around 7 to 5 can be separated in both acidic and basic PAGE systems, some isoforms could have been detected in both systems. Analysis by 2D-PAGE would solve this question and is actually in progress. The higher number of chitinase isoforms found in tomato roots, in comparison to those described for leaves (Joosten et al, 1995), can be attributed to a differential expression of chitinase genes in the various plant organs (leaves/roots/floral parts), as has been reported for tobacco (Trudel et al, 1989 ) and for other hydrolytic enzymes (Coté et al, 1991; El Ouakfaoui and Asselin, 1992). In the present study, control root extracts from tomato showed three major acidic chitinase isoforms, and several additional ones. These additional isoforms were, however, strongly stimulated after fungal infection with the pathogen $P n \vee$ parasiti$c a$, which is in agreement with data on regulation of chitinase expression during plant development and as a consequence of pathogenic infections (Collinge et al, 1993). With regard to basic chitinases, although no additional isoforms were induced by $P n \vee$ parasitica, a strong stimulation of the constitutive ones was detected. Increases in chitinase activities after inoculation with $P$ parasitica var nicotianae has been also reported in tobacco plants, where the infection caused a marked and parallel induction of chitinases and $\beta-1,3-$ glucanases, and an increase in the relative concentrations of mRNA encoding both enzymes (Meins and Ahl, 1989).

Transient activation of chitinases has been reported in several AM symbioses (Spanu et al, 1989; Lambais and Medhy, 1993; Vierheilig et al, 1994, 1995; Volpin et al, 1994), and this has been interpreted as a non-specific defence response to $A M$ fungi, which is then specifically repressed. Our results demonstrate the induction of one additional acidic chitinase isoform in tomato roots colonized by $G$ mosseae that differs from the isoforms overexpressed in plants infected by the pathogenic fungus $P n \vee$ parasitica; this confirms the differential induction of root chitinase isoforms after symbiotic or pathogenic fungal infection previously observed in plants such as tobacco (Dumas-Gaudot et al, 1992a) and pea (Dassi et al, 1996). Since none of the isoforms were found in extracts of either fungus alone (present work for $P n$ v parasitica and Slezack et al, 1996 for $G$ mosseae), it seems likely that they represent a differential reaction of the host plant to symbiotic and pathogenic interactions. It is noteworthy that the chitinase isoforms from extracts of mycorrhizal roots of tomato showed a better and quicker renaturation, after denaturation under non-reducing conditions, than those from control or pathogen-infected roots; this could be related to a different oxidative status of the mycorrhizal root cells (Arines et al, 1994b).

Mycorrhizal fungi do not appear to be sensitive to plant chitinases (Arlorio et al, 1992). These enzymes do not come into direct contact with the intracellular structures of AM fungi and do not 
bind to external hyphae, except when fungal cell wall soluble polysaccharides and proteins are eliminated by heat treatment (Spanu et al, 1989). In addition, overexpression of chitinase genes in transgenic Nicotiana does not affect the establishment and functioning of mycorrhizas, while such plants show an increased resistance to pathogens (Gianinazzi-Pearson et al, 1994; Vierheilig et al, 1995). The exact role and function of mycorrhiza-induced chitinase isoforms are still unclear (Dumas-Gaudot et al, 1996). It is possible to postulate that their induction may play some sort of role in bioprotection against soilborne pathogens. Phytophthora species are oomycetes, whose main cell wall component is $\beta$ 1,3-glucan, and which are usually believed to be devoid of chitin (Barnicki-Garcia, 1968); consequently, an antifungal role for chitinases appears unlikely. However, since further studies have reported the presence of glucosamine-containing polysaccharides in Phytophthora species (Bartnicki-García and Wang, 1983), we cannot rule out an active role for chitinases. Moreover, it seems reasonable to consider a synergistic effect with other hydrolytic enzymes, as in several plant-pathogen interactions it has been reported a coordinate induction of chitinases and $\beta-1,3-$ glucanases (Mauch et al, 1988a), and their synergistic activity in the degradation of fungal cell walls (Mauch et al, 1988b). Consequently, it can be hypothesized that the activity of this induced chitinase isoform in arbuscular mycorrhizae could help the plants to respond to invading pathogenic fungi either directly by its hydrolytic activity (alone or in synergy with other enzymes), or by releasing elicitors that quickly trigger the mechanisms involved in defence reactions.

\section{ACKNOWLEDGMENTS}

This work was partly supported by a European AIRProject (AIR Project 3 CT 94-0809) and the INRA Institute. MJ Pozo would like to thank the group from Laboratoire de Phytoparasitologie INRA Dijon, where the experiments have been carried out and especially B Dassi and A Samra for their constant support, and F Billerey for his kind help. Our acknowledgments to Dr J Palma and to $\mathrm{J}$ Grenier and $\mathrm{J}$ Trudel for their critical comments.

\section{REFERENCES}

Albrecht C, Asselin A, Piché Y, Lapeyrie F (1993) Comparison of Eucalyptus root chitinase patterns following inoculation by ectomycorrhizal or pathogenic fungi in vitro. In: Mechanisms of Plant Defence Responses, Developments in Plant Pathology, Vol 2 (B Fritig, M Legrand, eds), Kluwer Academic Publishers, Dordrecht, the Netherlands, 380

Arines J, Palma JM, Vilariño A (1993) Comparison of protein patterns in non-mycorrhizal and vesiculararbuscular mycorrhizal roots of red clover. New Phytol 123, 763-768

Arines J, Quintela M, Vilariño A, Palma JM (1994a) Protein patterns and superoxide dismutase activity in non-mycorrhizal and arbuscular mycorrhizal Pisum sativum L plants. Plant Soil 166, 37-45

Arines J, Vilariño A, Palma JM (1994b) Involvement of the superoxide dismutase enzyme in the mycorrhization process. Agric Sci Finn 3, 303-306

Arlorio M, Ludwig A, Boller T, Mischiati P, Bonfante P (1992) Effects of chitinase and $\beta-1,3$-glucanase from pea on the growth of saprophytic, pathogenic and mycorrhizal fungi. Giornale Botanico Italiano $126,956-958$

Audy P, Trudel J, Asselin A (1988) Purification and characterization of a lyzozyme from wheat germ. Plant Sci 58, 43-50

Bartnicki-Garcia S (1968) Cell wall chemistry, morphogenesis, and taxonomy of fungi. Annu Rev Microbiol $22,87-108$

Bartnicki-Garcia S, Wang MC (1983) Biochemical aspects of morphogenesis in Phytophthora. In: Phytophthora. Its Biology, Taxonomy, Ecology and Pathology (DC Erwin, S Bartnicki-García, PH Tsao, eds), The American Phytopathological Society Press, Saint Paul, MN, USA, 121-137

Benhamou N, Grenier J, Asselin A, Legrand M (1989) Immunogold localization of $\beta$-1,3-glucanases in two plants infected by vascular wilt fungi. Plant Cell 1 , 1209-1221

Benhamou N, Joosten MHAJ, de Wit PJGM (1990) Subcellular localization of chitinase and of its potential substrate in tomato root tissues infected by Fusarium oxysporum $\mathrm{f} \mathrm{sp}$ radicis-lycopersici. Plant Physiol 92, 1108-1120

Boller T (1993) Antimicrobial functions of the plant hydrolases, chitinase and $\beta-1,3-$ glucanase. In: Mechanisms of Plant Defence Responses (B Fritig, $M$ Legrand, eds), Kluwer Academic Publishers, Dordrecht, the Netherlands, 391-401

Collinge DB, Kragh KM, Mikkelsen JD, Nielsen KK, Rasmussen U, Vad K (1993) Plant chitinases. Plant J 3, 31-40

Cordier C, Gianinazzi-Pearson V, Gianinazzi S (1996) Colonization patterns of root tissues by Phytophthora nicotianae var parasitica related to reduce disease in mycorrhizal tomato. Plant Soil $185,223-232$

Coté F, Cutt JR, Asselin A, Klessing D (1991) Pathogenesis-related acidic $\beta$ - 1,3 -glucanase genes of tobacco are regulated by both stress and developmental signals. Mol Plant-Microbe Interact 4, 173-181 
Dassi B, Dumas-Gaudot E, Asselin A, Richard C, Gianinazzi $S$ (1996) Chitinase and $\beta$-1,3-glucanase isoforms expressed in pea roots inoculated with arbuscular mycorrhizal or pathogenic fungi. Eur $J$ Plant Pathol 102, 105-108

Davis BJ (1964) Disc electrophoresis. II. Method and application to human serum proteins. Ann NY Acad Sci $121,404-427$

Dumas E, Tahiri-Alaoui A, Gianinazzi S, GianinazziPearson V (1989) Observations on modifications in gene expression with VA endomycorrhiza development in tobacco: qualitative and quantitative changes in protein profiles. Endocytobiology 4, 153157

Dumas-Gaudot E, Furlan V, Grenier J, Asselin A (1992a) New acidic chitinase isoforms induced in tobacco roots by vesicular-arbuscular mycorrhizal fungi. Mycorrhiza 1, 133-126

Dumas-Gaudot E, Grenier J, Furlan V, Asselin A (1992b) Chitinase, chitosanase and $\beta-1,3-$ glucanase activities in Allium and Pisum roots colonized by Glomus species. Plant Sci 84, 17-24

Dumas-Gaudot E, Asselin A, Gianinazzi-Pearson V, Gollotte A, Gianinazzi S (1994a) Chitinase isoforms in roots of various pea genotypes infected with arbuscular mycorrhizal fungi. Plant Sci 99, 27-37

Dumas-Gaudot E, Guillaume P, Tahiri-Alaoui A, Gianinazzi-Pearson V, Gianinazzi S (1994b) Changes in polypeptide patterns in tobacco roots colonized by two Glomus species. Mycorrhiza 4, 215-221

Dumas-Gaudot E, Slezack S, Dassi B, Pozo MJ, Gianinazzi-Pearson V, Gianinazzi S (1996) Plant hydrolytic enzymes (chitinases and $\beta-1,3$-glucanases) in root reactions to pathogenic and symbiotic microorganisms. Plant Soil (in press)

El Ouakfaoui S, Asselin A (1992) Diversity of chitosanase activity in cucumber. Plant Sci 85, 33-41

Garcia-Breijo FJ, Garro R, Conejero V (1990) C7 (P32) and C6 (P34) PR proteins induced in tomato leaves by citrus exocortis viroid infection are chitinases. Physiol Mol Plant Pathol 36, 249-260

Gianinazzi-Pearson V, Gollotte A, Dumas-Gaudot E, Franken P, Gianinazzi S (1994) Gene expression and molecular modifications associated with plant responses to infection by arbuscular mycorrhizal fungi. In: Advances in Molecular Genetics of PlantMicrobe Interactions, Vol 3 (MJ Daniels, JA Downic, AE Osbourn, eds), Kluwer Academic Publishers, Dordrecht, the Netherlands, 179-186

Graham LS, Sticklen MB (1994) Plant chitinases. Can J Bot 72, 1057-1083

Granell A, Bellés JM, Conejero V (1987) Induction of pathogenesis-related proteins in tomato by citrus exocortis viroid, silver ion and ethephon. Physiol Mol Plant Pathol 31, 83-90

Hewitt EJ (1966) Sand and water culture methods used in the studies of plant nutrition. In: Technical communication, $\mathrm{Vol} 22$, Commonwealth Agricultural Bureau, London, UK, 430-434
Hooker JE, Jaizme-Vega M, Atkinson D (1994) Biocontrol of plant pathogens using arbuscular mycorrhizal fungi. In: Impact of Arbuscular Mycorrhizas on Sustainable Agriculture and Natural Ecosystems (S Gianinazzi, H Schüepp, eds), Birkhaüser-Verlag, Basel, Switzerland, 191-200

Joosten MHAJ, de Wit PJGM (1989) Identification of several pathogenesis-related proteins in tomato leaves inoculated with Cladosporium fulvum (syn Fulvia fulva) as $1,3-\beta$-glucanases and chitinases. Plant Physiol 89, 945-951

Joosten MHAJ, Verbakel HM, Nettekoven ME, van Leeuwen J, van der Vossen RTM, de Wit PJGM (1995) The phytopathogenic fungus Cladosporium fulvum is not sensitive to the chitinase and $\beta-1,3$ glucanase defence proteins of its host, tomato. Physiol Mol Plant Pathol 46, 45-59

Lambais MR, Mehdy MC (1993) Suppression of endochitinase, $\beta-1,3$ endoglucanase, and chalcone isomerase expression in bean vesicular-arbuscular mycorrhizal roots under different soil phosphate conditions. Mol Plant-Microbe Interact 6, 75-83

Linderman RG (1994) Role of VAM fungi in biocontrol. In: Mycorrhizae and Plant Health (FL Pfleger, RG Linderman, eds), The American Phytopathological Society Press, St Paul, MN, USA, 1-27

Mauch F, Hadwiger LA, Boller T (1988a) Antifungal hydrolases in pea tissue. I. Purification and characterization of two chitinases and two $\beta-1,3$-glucanases differentially regulated during development and in response to fungal infection. Plant Physiol 87, 325-333

Mauch F, Mauch-Mani B, Boller T (1988b) Antifungal hydrolases in pea tissue. II. Inhibition of fungal growth by combinations of chitinase and $\beta-1,3$-glucanase. Plant Physio/ 88, 936-942

Meins F, Ahl P (1989) Induction of chitinase and $\beta-1,3$ glucanase in tobacco plants infected with Pseudomonas tabacci and Phytophthora parasitica var nicotianae. Plant Sci61, 155-161

Pacovsky RS (1989) Carbohydrate, protein and aminoacid status of Glycine-Glomus-Bradyrhizobium symbiosis. Physiol Plant 75, 346-354

Pan SQ, Ye XS, Kuc J (1991) A technique for detection of chitinase, $\beta-1,3$-glucanase, and protein patterns after a single separation using polyacrylamide gel electrophoresis or isoelectrofocusing. Phytopathology 81, 970-974

Pegg JR, Young JH (1982) Purification and characterization of chitinase enzymes from healthy and Verticillium albo-atrum-infected tomato plants and from V albo-atrum. Physiol Plant Pathol 21, 389-409

Phillips JM, Hayman DE (1970) Improved procedures for clearing roots and staining parasitic and vesicular-arbuscular mycorrhizal fungi for rapid assessment of infection. Trans Br Mycol Soc 55, 158-161

Reisfeld RA, Lewis VJ, Williams DE (1962) Disk electrophoresis of basic proteins and peptides on polyacrylamide gels. Nature 195, 281-283 
Schellenbaum L, Gianinazzi S, Gianinazzi-Pearson V (1993) Comparison of acid soluble protein synthesis in roots of endomycorrhizal wild type Pisum sativum and corresponding isogenic mutants. J Plant Physiol 141, 2-6

Slezack S, Dassi B, Dumas-Gaudot E (1996) Arbuscular mycorrhiza-induced chitinase isoforms. In: Book of the Extended Summaries, 2nd International Symposium on Chitin Enzymology (RAA Muzzarelli, ed), Atec Edizioni, Grottammare, Italy, 2, 339-347

Spanu P, Boller T, Ludwig A, Wiemken A, Faccio A, Bonfante-Fasolo $P$ (1989) Chitinase in roots of mycorrhizal Allium porrum: regulation and localization. Planta 177, 447-455

Staehelin C, Muller J, Mellor RB, Wiemken A, Boller T (1992) Chitinase and peroxidase in effective (fix ${ }^{+}$) and ineffective (fix ${ }^{-}$) soybean nodules. Planta 187 , 295-300

Trouvelot A, Kough JL, Gianinazzi-Pearson V (1986) Mesure du taux de mycorhization d'un système radiculaire. Recherche d'une méthode d'estimation ayant une signification fonctionnelle. In: Physiological and Genetical Aspects of Mycorrhizae (V Gianinazzi-Pearson, S Gianinazzi, eds), INRA Press, Paris, France, 217-221

Trudel J, Asselin A (1989) Detection of chitinase activity after polyacrylamide gel electrophoresis. Ann Biochem 178, 362-366

Van Kan JAL, Joosten HAJ, Wagemakers CAM, Van der Berg-Velthuis GCM, de Wit PJGM (1992) Differential accumulation of mRNAs encoding extracellular and intracellular PR proteins in tomato induced by virulent and avirulent races of Cladosporium fulvum. Plant Mol Biol 20, 513-527

Vierheilig $\mathrm{H}$, Alt $\mathrm{M}$, Mohr U, Boller T, Wiemken A (1994) Ethylene biosynthesis and activities of chitinase and $\beta-1,3$ glucanase in the roots of host and non-host plants of vesicular-arbuscular mycorrhizal fungi after inoculation with Glomus mosseae. J Plant Physiol 143, 337-343

Vierheilig $\mathrm{H}$, Alt M, Lange J, Gut-Rella M, Wiemken A, Boller T (1995) Colonization of tobacco constitutively expressing pathogenesis-related proteins by the vesicular-arbuscular mycorrhizal fungus Glomus mosseae. Appl Environ Microbiol 61, 3031-3034

Volpin H, Elkind Y, Okon Y, Kapulnik Y (1994) A vesicular arbuscular mycorrhizal fungus (Glomus intraradix) induces a defense response in alfalfa roots. Plant Physiol 104, 683-689

Wessels JGH, Sietsma JH (1981) Fungal cell walls: a survey. In: Encyclopedia of Plant Physiol, New series, Plant Carbohydrates II (W Tanner, FA Loewus, eds), Springer-Verlag, Berlin, Germany, 352-394

Wubben JP, Joosten MHAJ, Van Kan JAL, de Wit PJGM (1992) Subcellular localization of plant chitinases and $1,3,-\beta$-glucanases in Cladosporium fulvum (syn Fulvia fulva)-infected tomato leaves. Physiol Mol Plant Pathol 41, 23-32

Wyss P, Mellor RB, Wiemken A (1990) Vesiculararbuscular mycorrhizal of wild-type soybean and non-nodulating mutants with Glomus mosseae contain symbiosis-specific polypeptides (Mycorrhizins) immunologically cross-reactive with nodulins. Planta $182,22-26$ 